\title{
Phytochemical Constituents, Antioxidant Activity, and Toxicity Assessment of the Seed of Spondias mombin L. (Anacardiaceae)
}

\author{
Spondias mombin L. (Anacardiaceae) Tohumunun Fitokimyasal Bileşenleri, \\ Antioksidan Aktivitesi ve Toksisite Değerlendirmesi
}

\author{
(D) Oyindamola Olajumoke ABIODUN*, (D) Mesoma Esther NNORUKA, (D) Rasidat Olufunke TIJANI \\ University of Ibadan College of Medicine, Department of Pharmacology and Therapeutics, Ibadan, Nigeria
}

\begin{abstract}
Objectives: Increased generation of free radicals exceeding the antioxidant capacity of the host is deleterious. Thus new, potent, and safe antioxidants will be a valuable addition to the limited antioxidant arsenals available. Therefore, the antioxidant activity, cytotoxicity potential, and phytochemical constituents of the methanol extract of Spondias mombin seed (MESSM) were investigated.

Materials and Methods: 2,2-diphenyl-1-picrylhydrazyl (DPPH), nitric oxide (NO), and hydrogen peroxide $\left(\mathrm{H}_{2} \mathrm{O}_{2}\right)$ were the antioxidant assays used. The cytotoxicity of MESSM was evaluated against a rhabdomyosarcoma (RD) cell line in a 3-(4,5-dimethylthiazol-2-yl)-2,5-diphenyl tetrazolium bromide based assay. The phytochemical constituents of MESSM were identified using gas chromatography-mass spectrometry.

Results: MESSM produced better antioxidant activity in the DPPH $\left(\mathrm{IC}_{50}=58.64 \pm 1.49 \mu \mathrm{g} / \mathrm{mL}\right)$ and $\mathrm{H}_{2} \mathrm{O}_{2}\left(\mathrm{IC}_{50}=44.03 \pm 5.57 \mu \mathrm{g} / \mathrm{mL}\right)$ assays than in the NO ( $\mathrm{IC}_{50}=494.55 \pm 12.68 \mu \mathrm{g} / \mathrm{mL}$, p $\left.<0.0001\right)$ assay. Moreover, MESSM was nontoxic $\left(\mathrm{CC}_{50}=139.6 \pm 0.54 \mu \mathrm{g} / \mathrm{mL}\right)$ in comparison to cyclophosphamide $\left(\mathrm{CC}_{50}=0.97 \pm 0.03 \mu \mathrm{g} / \mathrm{mL}\right)$ against the RD cell line. The major compounds in MESSM were dodecanoic acid (22.48\%), tetradecanoic acid (17.95\%), n-hexadecanoic acid (15.35\%), capsaicin (12.11\%), and dihydrocapsaicin (5.23\%).

Conclusion: The seed extract of Spondias mombin contains nontoxic antioxidant compounds that could be explored in the pharmaceutical and cosmetics industries for the development of antioxidant agents.
\end{abstract}

Key words: Seed of Spondias mombin, antioxidants, cytotoxicity, GC-MS

öz

Amaç: Konağın antioksidan kapasitesini aşan serbest radikallerin artması zararlıdır. Bu nedenle, yeni, güçlü ve güvenli antioksidanlar, mevcut sınırlı antioksidanlara değerli katkı sağlayacaktır. Bu nedenle, Spondias mombin tohumunun (MESSM) metanol ekstraktının antioksidan aktivitesi, sitotoksisite potansiyeli ve fitokimyasal bileşenleri araştırıldı.

Gereç ve Yöntemler: 2,2-difenil-1-pikrilhidrazil (DPPH), nitrik oksit (NO) ve hidrojen peroksit $\left(\mathrm{H}_{2} \mathrm{O}_{2}\right)$ kullanılan antioksidan deneylerdi. MESSM'nin sitotoksisitesi, 3-(4,5- dimetil tiyazol-2-yl)-2,5- difenil tetrazolium bromür ile bir rabdomiyosarkom (RD) hücre hattında değerlendirildi. MESSM'nin fitokimyasal bileșenleri gaz kromatografisi-kütle spektrometresi kullanılarak tanımlandı.

Bulgular: MESSM, DPPH $\left(\mathrm{IC}_{50}=58,64 \pm 1,49 \mu \mathrm{g} / \mathrm{mL}\right)$ ve $\mathrm{H}_{2} \mathrm{O}_{2}\left(\mathrm{IC}_{50}=44,03 \pm 5,57 \mu \mathrm{g} / \mathrm{mL}\right)$ deneylerinde $\mathrm{NO}\left(\mathrm{IC}_{50}=494,55 \pm 12,68 \mu \mathrm{g} / \mathrm{mL}, \mathrm{p}<0,0001\right)$ deneyinden daha iyi antioksidan aktivite gösterdi. Ayrıca, MESSM'in RD hücre hattına karşı siklofosfamide $\left(C_{50}=0,97 \pm 0,03 \mu \mathrm{gg} / \mathrm{mL}\right) \mathrm{kıyasla} \mathrm{toksik}$ olmadığı $\left(C_{50}=139,6 \pm 0,54 \mu \mathrm{g} / \mathrm{mL}\right.$ ) bulundu. MESSM'deki ana bileşiklerin, dodekanoik asit $(\% 22,48)$, tetradekanoik asit (\%17,95), n-heksadekanoik asit $(\% 15,35)$, kapsaisin (\% 12,11) ve dihidrokapsaisin (\% 5,23) olduğu bulundu.

Sonuç: Spondias mombin'in tohum ekstresinin, ilaç ve kozmetik endüstrilerinde antioksidan ajanların geliştirilmesi için araștırılabilecek toksik olmayan antioksidan bileşikler içerdiği sonucuna varıldı.

Anahtar kelimeler: Spondias mombin tohumu, antioksidanlar, sitotoksisite, GC-MS

*Correspondence: E-mail: oyindamolaabiodun1@gmail.com, Phone: +234 7030964774 ORCID-ID: orcid.org/0000-0002-6629-3016

Received: 25.04.2019, Accepted: 11.05.2020

Turk J Pharm Sci, Published by Galenos Publishing House. 


\section{INTRODUCTION}

Free radicals such as reactive oxygen species (ROS) in the form of superoxide anion $\left(\mathrm{O}_{2}\right)$, hydroxyl radical, and hydrogen peroxide $\left(\mathrm{H}_{2} \mathrm{O}_{2}\right)$, and reactive nitrogen species (NOS) in the form of nitric oxide (NO) radical are by-products of the human body's metabolism and can also be generated from exogenous stimuli.' A physiological amount of ROS is considered to function in signal delivering while an excessive amount damages DNA, proteins, and lipids, which can induce cell death, implicated in the pathogenesis of cancer, ageing, ${ }^{2}$ ophthalmological diseases, ${ }^{3}$ cardiovascular diseases, ${ }^{4}$ and many general neurodegenerative pathologies like Alzheimer's disease, ${ }^{5}$ Parkinson's disease, ${ }^{6}$ and prion disease. ${ }^{7}$

Excessive ROS are neutralized by a controlled and balanced complex web of antioxidant defenses in the body. ${ }^{8}$ Antioxidants help to minimize the effect of free radicals on biomolecules by scavenging them. However, if production of free radicals overwhelms the biological antioxidants, there will be a need for introduction of an external source of antioxidants. An external source of antioxidants offers a promising way to prevent the deleterious effect of excessive exposure to ROS. ${ }^{8}$ It has been reported by previous studies that phytochemicals such as flavonoids and polyphenols can help in preventing the development of chronic diseases. ${ }^{9}$ Moreover, the use of extracts from pomegranate, green tea, grape seed, and mushrooms as antioxidants in skin care products to prevent the clinical signs of photoaging is on the increase.,10 Thus, the interest in naturally occurring antioxidants in foods, cosmetics, and pharmaceutical products has significantly increased. Prolonged use of antioxidants necessitates the need for safe and effective antioxidants that the natural agents symbolize, unlike the synthetic antioxidants that have been associated with toxicity ${ }^{11}$ and carcinogenic effects ${ }^{12}$ after prolonged use.

There is a need to search for more antioxidants of natural origin that can be added to the limited arsenals of antioxidants available. Spondias mombin (S. mombin) is a fructiferous tree that is commonly found in Nigeria, Brazil, Peru, southern Mexico, Sierra Leone, Equatorial Guinea and Côte d'Ivoire.13 In Nigeria, it is commonly known as iyeye in the Yoruba ethnomedicine. Antidiarrheal, antimicrobial, diuretic, febrifuge, and emetic activities of the fruit, leaf, or bark of S. mombin leaf have been reported. ${ }^{14-18}$ The flower, leaf, or bark are used for wound healing and to treat stomachache and various inflammatory conditions. ${ }^{19}$ Antioxidant activity of the leaf and fruit has been reported. ${ }^{20,21}$ Despite the information on the leaf, fruit, flower, and stem bark of S. mombin, little is known about the usefulness of its seed, which is considered a waste product. Therefore, we report the antioxidant, cytotoxicity, and phytochemical composition of the seed of S. mombin.

\section{MATERIALS AND METHODS}

\section{Reagents}

Sodium bicarbonate, sodium hydroxide, 2,2-diphenyl-1-picrylhydrazyl (DPPH), rutin, Folin-Ciocalteu reagent, rutin, gallic acid, ascorbic acid, sodium nitroprusside, sulfanilamide, N-naphthyl- ethylenediamine dihydrochloride, and 3-(4,5-dimethylthiazol-2yl)-2,5-diphenyl tetrazolium bromide (MTT) were obtained from Sigma Aldrich Co., St. Louis, MO, USA.

\section{Plant collection}

The fresh fruit of $S$. mombin was collected behind the Pharmacology and Therapeutics building, University of Ibadan on 20 September 2017. Identification of the plant was done by Mr. D. P. Esimekhuai of the Botany Department, University of lbadan (UIH-22764).

\section{Plant extraction}

The fleshy part of the $S$. mombin fruit was removed completely; thereafter the seed was oven dried at $40{ }^{\circ} \mathrm{C}$ and pulverized. The maceration method of extraction was employed by soaking $203 \mathrm{~g}$ of $S$. mombin seed in a mixture of methanol:water (70:30) for 72 $\mathrm{h}$. The solvent was removed at reduced pressure and temperature in order to obtain the extract, which was kept at $4^{\circ} \mathrm{C}$.

\section{Total phenolic content (TPC)}

The determination of the TPC of methanol extract of Spondias mombin (MESSM) was carried out by following the procedures of a previously reported method. ${ }^{22}$ Briefly, $0.1 \mathrm{~mL}$ of MESSM $(1 \mathrm{mg} / \mathrm{mL}$ ) and $0.1 \mathrm{~mL}$ of Folin-Ciocalteu phenol were mixed and left for $5 \mathrm{~min}$. Thereafter, $1 \mathrm{~mL}$ of $7 \% \mathrm{Na}_{2} \mathrm{CO}_{3}$ and $1.3 \mathrm{~mL}$ of distilled water were added. The mixture was allowed to stand for $90 \mathrm{~min}$ at $29{ }^{\circ} \mathrm{C}$. Optical density (OD) was obtained at $750 \mathrm{~nm}$. The TPC was estimated in triplicate and expressed as milligrams of gallic acid equivalents (GAE) per gram of the dried seed of S. mombin.

\section{Total flavonoid content (TFC)}

The determination of MESSM TFC was done according to a previously reported method. ${ }^{23}$ First, $0.3 \mathrm{~mL}$ of MESSM (1 mg/ $\mathrm{mL}), 0.15 \mathrm{~mL}$ of $\mathrm{AlCl}_{3} .6 \mathrm{H}_{2} \mathrm{O}(0.3 \mathrm{M}), 0.15 \mathrm{~mL}$ of $\mathrm{NaNO}_{2}(0.5 \mathrm{M})$, and $3.4 \mathrm{~mL}$ of methanol (30\%) were mixed. After $5 \mathrm{~min}$, the reaction was stopped with $1 \mathrm{~mL}$ of $\mathrm{NaOH}(1 \mathrm{M})$. The absorbance was obtained at $506 \mathrm{~nm}$. The TFC was estimated in triplicate and expressed as milligrams of rutin equivalents (RE) per gram of the dried seed of S. mombin.

\section{Antioxidant assays of MESSM}

\section{DPPH assay}

A modified version of the method described by Silva et al. ${ }^{24}$ was followed. Briefly, gradient concentrations of MESSM (6.25$400 \mu \mathrm{g} / \mathrm{mL}$ ) or the standard drug ascorbic acid $(0.25-16 \mu \mathrm{g} /$ $\mathrm{mL}$ ) were prepared in ethanol and incubated with $0.04 \mathrm{mg} / \mathrm{mL}$ DPPH (1:1.5 vol/vol) for $30 \mathrm{~min}$ at $29{ }^{\circ} \mathrm{C}$ in the dark. OD was obtained at $517 \mathrm{~nm}$ and expressed as percentage of the control.

\section{Hydrogen peroxide assay}

A previously reported method was used. ${ }^{25} \mathrm{H}_{2} \mathrm{O}_{2}$ free radical was generated from $\mathrm{H}_{2} \mathrm{O}_{2}$ solution. Briefly, $2 \mathrm{mM}$ of freshly prepared $\mathrm{H}_{2} \mathrm{O}_{2}(6: 1 \mathrm{v} / \mathrm{v})$ was mixed with gradient concentrations of MESSM (6.25 to $400 \mu \mathrm{g} / \mathrm{mL})$ or ascorbic acid $(2.5-160 \mu \mathrm{g} / \mathrm{mL})$. The mixture was left in the dark for $10 \mathrm{~min}$ at $29^{\circ} \mathrm{C}$. Thereafter, absorbance was recorded at $230 \mathrm{~nm}$. 


\section{Nitric oxide assay}

Briefly, sodium nitroprusside in aqueous solution ( $40 \mathrm{mM}$ ) was added to graded concentrations $(50-800 \mu \mathrm{g} / \mathrm{mL})$ of MESSM $(1: 4 \mathrm{v} / \mathrm{v})$ and kept in the dark at $29^{\circ} \mathrm{C}$ for $2 \mathrm{~h}$. Subsequently, the resulting solution was mixed with Griess reagent (1:1 v/v) and kept for $15 \mathrm{~min}$ in the dark at $29^{\circ} \mathrm{C} .{ }^{26}$ Absorbance was obtained at $550 \mathrm{~nm}$ and the amount of $\mathrm{NO}$ in each of the wells was estimated from the sodium nitrite curve. Ascorbic acid at 2.5-160 $\mu \mathrm{g} / \mathrm{mL}$ served as the standard drug.

\section{Data analysis for antioxidant assays}

OD values of MESSM or ascorbic acid in all the antioxidant assays were calculated and represented as the percentage of the negative control. Percentage scavenging activity in respect to the negative control was calculated. The $50 \%$ inhibitory concentration of MESSM $\left(\mathrm{IC}_{50}\right)$ was determined using linear regression in a commercial statistical package, Origin ${ }^{\circledR}$.

Toxicity assessment of MESSM against the rhabdomyosarcoma (RD) cell line

A published method was used. ${ }^{27}$ Briefly, a ten-fold serial dilution of $1 \mathrm{mg} / \mathrm{mL}$ MESSM was prepared in culture media resulting in $0.01-1000 \mu \mathrm{g} / \mathrm{mL}$. A confluent monolayer of RD cells cultured in a microtiter plate for $24 \mathrm{~h}$ was incubated with the graded concentrations of MESSM or cyclophosphamide (positive control) at $37{ }^{\circ} \mathrm{C}$ in $5 \% \mathrm{CO}_{2}$. After $72 \mathrm{~h}, 25 \mu \mathrm{L}$ of $2 \mathrm{mg} / \mathrm{mL}$ MTT solution was added and further incubation was done for $1.5 \mathrm{~h}$ at $37{ }^{\circ} \mathrm{C}$ in $5 \% \mathrm{CO}_{2}$. Finally, $125 \mu \mathrm{L}$ of DMSO was added to the cells and they were agitated for $15 \mathrm{~min}$. Absorbance was recorded at $492 \mathrm{~nm}$ and expressed as percentage of the negative control. The 50\% cytotoxic concentration $\left(\mathrm{CC}_{50}\right)$ was determined using nonlinear regression in GraphPad Prism $5^{\circledR}$.

Chemical composition of MESSM using gas chromatographymass spectrometry (GC-MS)

In the identification of the phytochemical constituents of MESSM, GC-MS was used according to a previously described method. ${ }^{28}$ The model of the instrument used was an Agilent Technologies 7890 GC system with a 5975 MC detector. The mobile phase was a carrier gas, helium (99.99\% purity), and the column was an HP5 MS $30 \mathrm{~m}$ in length, $0.320 \mathrm{~mm}$ in internal diameter, and $0.25 \mu \mathrm{m}$ in thickness. To identify the compounds, the retention time and fragmentation pattern were compared to the NIST library database.

\section{Statistical analysis}

The antioxidant and cytotoxicity assays were performed in duplicate and repeated in three independent experiments. The $\mathrm{IC}_{50}$ or $\mathrm{CC}_{50}$ values were expressed as mean \pm standard error of mean. The mean $I_{50}$ or $\mathrm{CC}_{50}$ of the MESSM was compared to that of the standard drug using the Mann-Whitney $U$ test and difference was significant at $p<0.05$.

\section{RESULTS}

The percentage yield, following the extraction of MESSM in $70 \%$ methanol, was $2.72 \%$. The TPC and TFC of MESSM were $239.50 \pm 7.9 \mathrm{mg} \mathrm{GAE} / \mathrm{g}$ sample and $105.3 \pm 3.6 \mathrm{mg}$ RE/g sample, respectively. In addition, the $\mathrm{IC}_{50}$ of MESSM in the $\mathrm{DPPH}$, hydrogen peroxide, and NO scavenging assays was $58.64 \pm 1.49$, 44.03 \pm 5.57 , and $494.55 \pm 12.68 \mu \mathrm{g} / \mathrm{mL}$, respectively (Table 1). Ascorbic acid, the standard drug used in the 3 antioxidants assays, gave an $\mathrm{IC}_{50}$ of $4.31 \pm 0.26,10.63 \pm 0.31$, and $48.74 \pm 1.46$ $\mu \mathrm{g} / \mathrm{mL}$, respectively. Moreover, MESSM and cyclophosphamide showed $\mathrm{CC}_{50}$ of $139.6 \pm 0.54$ and $0.97 \pm 0.03 \mu \mathrm{g} / \mathrm{mL}$, respectively, on the RD cell line in the cytotoxicity assay. The GC-MS chromatogram of MESSM showed 21 distinct peaks (Figure 1) corresponding to 21 compounds (Table 2). The identified compounds can be grouped into alkanes (42.86\%), fatty acids (28.57\%), phenol amide (9.52\%), phenolic lipids (9.52\%), saponin (4.76\%), and terpenoids (4.76\%). Peaks 3, 7, 12, 18, and 19 represent dodecanoic acid, the most abundant (22.48\%), followed by tetradecanoic acid (17.95\%), n-hexadecanoic acid (15.35\%), capsaicin (12.11\%), and dihydrocapsaicin $(5.23 \%)$. The $\mathrm{m} / \mathrm{z}$, fragmentation pattern, and structures of dodecanoic acid, tetradecanoic acid, n-hexadecanoic acid, capsaicin, and dihydrocapsaicin are presented in Figures 2-6.

\section{DISCUSSION}

The seed extract of $S$. mombin contains nontoxic antioxidant components. Ascorbic acid, a standard drug, had better activity than the MESSM, a crude extract. Purification of this extract might yield more potent compounds. In the present study, MESSM was 8-11 times less active in scavenging NO free radicals than scavenging the DPPH and $\mathrm{H}_{2} \mathrm{O}_{2}$ free radicals. In water, plants, the human body, food, microorganisms, and air, $\mathrm{H}_{2} \mathrm{O}_{2}$ occurs in low quantities. ${ }^{12}$ The decomposition of $\mathrm{H}_{2} \mathrm{O}_{2}$ yields hydroxyl radicals, which can damage DNA and cause lipid peroxidation. ${ }^{29}$ Similar reports on the antioxidant activity of other components of $S$. mombin have been published. ${ }^{20,21,30}$ However, it appears this is the first report of the antioxidant activity of the seed of S. mombin. The seed, a waste product, has not been investigated. In the spirit of turning waste into wealth, this study was performed. In order to rule out the toxicity of MESSM, its cytotoxicity was evaluated. The MESSM was 143 times less toxic than cyclophosphamide, the standard drug against RD cells. This implies MESSM is nontoxic to RD cells.

Table 1. In vitro antioxidant activity and toxicity assessment of methanol extract of the seed of Spondia mombin (MESSM)

\begin{tabular}{|c|c|c|}
\hline \multirow[t]{2}{*}{ In vitro assays } & \multicolumn{2}{|l|}{$\mathrm{IC}_{50}(\mu \mathrm{g} / \mathrm{mL})$} \\
\hline & MESSM & $\begin{array}{l}\text { Standard } \\
\text { drugs }\end{array}$ \\
\hline \multicolumn{3}{|l|}{ Antioxidant } \\
\hline DPPH radical scavenging & $58.64 \pm 1.49^{*}$ & $4.31 \pm 0.26^{a}$ \\
\hline $\begin{array}{l}\text { Hydrogen peroxide radical } \\
\text { scavenging }\end{array}$ & $44.03 \pm 5.57^{\star}$ & $10.63 \pm 0.31^{\mathrm{a}}$ \\
\hline Nitric oxide radical scavenging & $494.55 \pm 12.68^{\star}$ & $48.74 \pm 1.41^{\mathrm{a}}$ \\
\hline \multicolumn{3}{|l|}{ Cytotoxicity } \\
\hline Using rhabdomyosarcoma cell line & $139.6 \pm 0.54^{* *}$ & $0.97 \pm 0.03^{b}$ \\
\hline
\end{tabular}




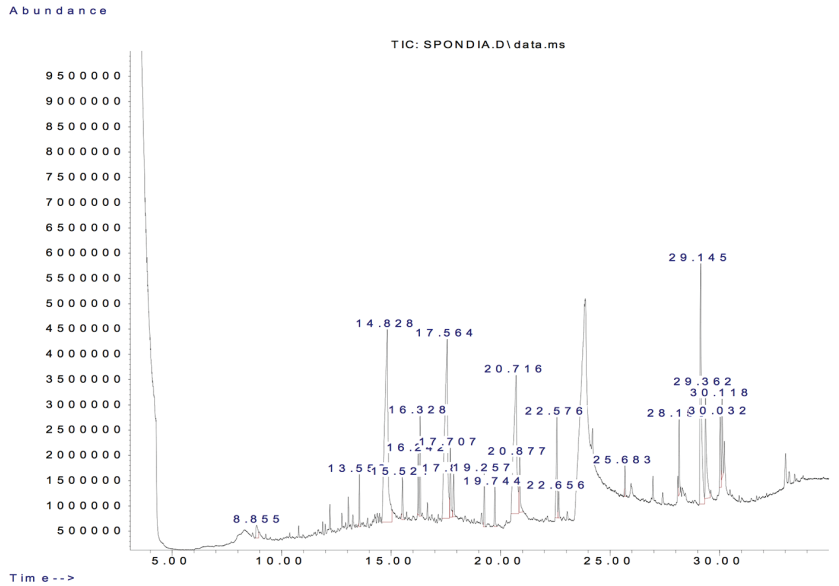

Figure 1. A gas chromatogram showing a plot of intensity against retention time (minutes)

In addition, MESSM showed high total flavonoid and phenolic contents. Phenolic compounds are secondary metabolites that contain hydroxyl groups that confer them with scavenging ability. The MESSM had a higher phenolic content (>100) than some fruits such as S. mombin, guava, strawberry, pineapple, soursop, and passion fruit. 21,31 $^{2}$

The following major compounds were identified in the seed of S. mombin: dodecanoic acid (22.48\%), tetradecanoic acid (17.95\%), n-hexadecanoic acid (15.35\%), and phenol amides capsaicin (12.11\%) and dihydrocapsaicin (5.23\%). Dodecanoic acid, also known as lauric acid, showed in vitro antimicrobial activity against Propionibacterium acnes and beneficial effects in a mouse ear model of Propionibacterium acnes-induced inflammation. ${ }^{32}$ Lauric acid is one of the reagents for making soaps and cosmetics. ${ }^{33}$ Tetradecanoic acid (myristic acid), another constituent of MESSM, is used as a dietary supplement and a flavoring agent in the food industry. It is also used in the cosmetic industry, for making toiletries, emulsifiers, facial creams, and lotions, and in the pharmaceutical industry. 34,35 Furthermore, hexadecanoic acid (palmitic acid) possesses antioxidant, anticancer, and anti-inflammatory activities. ${ }^{36-39}$ Capsaicin and dihydrocapsaicin, other constituents of MESSM, are phenol amides, majorly found in pepper. Capsaicin and dihydrocapsaicin possess antioxidant activity. ${ }^{40}$ Capsaicin is also used for the treatment of pain. It can be administered in topical ointments, nasal sprays, and dermal patches ${ }^{41} \mathrm{~A}$ transdermal patch of capsaicin (Qutenza ${ }^{\circledR}$ ) was approved by the Food and Drug Administration for the management of pain due to postherpetic neuralgia. ${ }^{42}$ Other minor compounds in the seed of $S$. mombin with antioxidant activity that have been previously reported include $(9 Z, 12 Z)$-9,12-octadecadienoic acid (linoleic acid), 4-H-pyran-4-one, 2.3-dihydro-3.5-dihydroxy-6-methyl, and hexadecanoic acid-methyl ester. ${ }^{43}$

\section{CONCLUSION}

The seed extract of S. mombin lacked cytotoxicity potential. It contains nontoxic antioxidant compounds that could be explored in the pharmaceutical and cosmetics industries for the development of antioxidant agents.
Table 2. Chemical components of methanol extract of Spondias mombin using GC-MS

$\mathrm{S} / \mathrm{N}$ Compound

Peak GC-MS-RT Percentage $\mathrm{M} / \mathrm{Z}$ no. (min) abundance value (\%)

\begin{tabular}{|c|c|c|c|c|c|}
\hline & Saponin & & & & \\
\hline \multirow[t]{2}{*}{1} & $\begin{array}{l}\text { 4H-Pyran-4- } \\
\text { one,2,3-dihydro-3,5- } \\
\text { dihydroxy-6-methyl- }\end{array}$ & 1 & 8.86 & 0.90 & 144 \\
\hline & Alkanes & & & & \\
\hline 2 & Pentadecane & 2 & 13.55 & 1.05 & 212 \\
\hline 3 & $\begin{array}{l}\text { Pentadecane, } \\
\text { 2,6,11-trimethyl- }\end{array}$ & 4 & 15.52 & 1.15 & 254 \\
\hline 4 & Heptadecane & 5 & 16.24 & 1.36 & 240 \\
\hline 5 & $\begin{array}{l}\text { Pentadecane, } \\
\text { 2,6,10,14-tetramethyl }\end{array}$ & 6 & 16.33 & 2.63 & 268 \\
\hline 6 & Octadecane & 8 & 17.71 & 2.21 & 254 \\
\hline 7 & $\begin{array}{l}\text { Hexadecane, } \\
\text { 2,6,10,14-tetramethyl- }\end{array}$ & 9 & 17.86 & 1.33 & 282 \\
\hline 8 & Nonadecane & 10 & 19.26 & 1.41 & 268 \\
\hline 9 & Eicosane & 13 & 20.88 & 1.92 & 282 \\
\hline 10 & $\begin{array}{l}\text { Octadecane, } \\
\text { 1-bromo- }\end{array}$ & 16 & 25.68 & 0.76 & 332 \\
\hline
\end{tabular}

Fatty acid

\begin{tabular}{|c|c|c|c|c|c|}
\hline 11 & Dodecanoic acid & 3 & 14.83 & 22.48 & 200 \\
\hline 12 & Tetradecanoic acid & 7 & 17.56 & 17.95 & 228 \\
\hline 13 & $\begin{array}{l}\text { Hexadecanoic acid, } \\
\text { methyl ester }\end{array}$ & 11 & 19.74 & 1.13 & 270 \\
\hline 14 & n-Hexadecanoic acid & 12 & 20.72 & 15.35 & 256 \\
\hline 15 & $\begin{array}{l}\text { 9,12-Octadecadienoic } \\
\text { acid }(Z, Z) \text {-methyl } \\
\text { ester }\end{array}$ & 14 & 22.58 & 3.92 & 294 \\
\hline \multirow[t]{2}{*}{16} & $\begin{array}{l}\text { 11-Octadecenoic acid, } \\
\text { methyl ester }\end{array}$ & 15 & 22.66 & 0.76 & 335 \\
\hline & Phenolic lipids & & & & \\
\hline 17 & $\begin{array}{l}\text { (Z)-3-(pentadec-8- } \\
\text { en-1-yl) phenol }\end{array}$ & 17 & 28.16 & 1.95 & 302 \\
\hline \multirow[t]{2}{*}{18} & $\begin{array}{l}\text { 3-(4Z,7Z)- } \\
\text { Heptadeca-4,7-dien- } \\
\text { 1-yl) phenol }\end{array}$ & 20 & 30.03 & 2.32 & 328 \\
\hline & Phenol amide & & & & \\
\hline 19 & Capsaicin & 18 & 29.15 & 12.11 & 305 \\
\hline \multirow[t]{2}{*}{20} & Dihydrocapsaicin & 19 & 29.36 & 5.23 & 307 \\
\hline & Monoterpenoids & & & & \\
\hline 21 & Pyridine, 2-ethoxy- & 21 & 30.12 & 2.09 & 123 \\
\hline
\end{tabular}

GC-MS: Gas chromatography-mass spectrometry, RT: Retention time

\section{ACKNOWLEDGEMENTS}

The technical assistance of Ms. Faridah Abdulhameed and Owoola Azizat during the course of the study is acknowledged. 


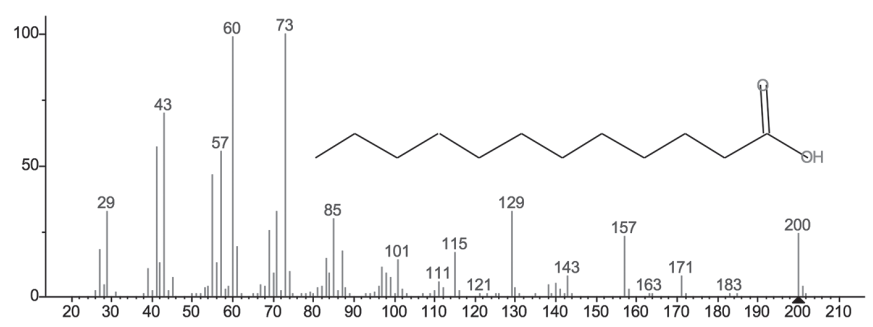
(mainlib) Dodecanoic acid

Figure 2. Profile of mass spectra and chemical structure of dodecanoic acid present in seed of Spondias mombin

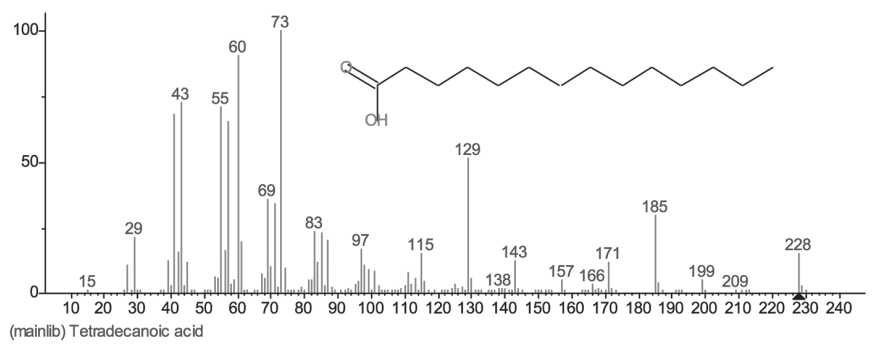

Figure 3. Mass spectra of tetradecanoic acid, a plot of relative abundance against mass to charge ratio

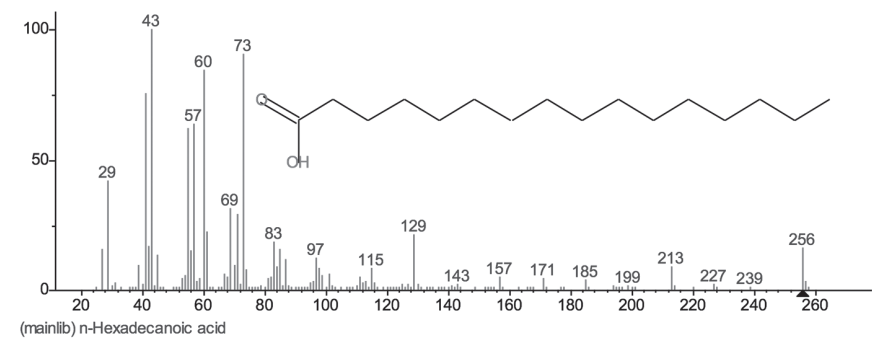

Figure 4. Mass spectra of $n$-hexadecanoic acid, a plot of relative abundance against mass to charge ratio

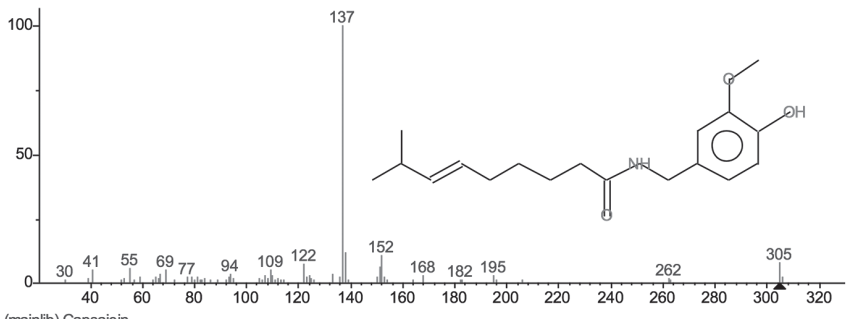

(mainlib) Capsaicin

Figure 5. Mass spectra of capsaicin, a plot of relative abundance against mass to charge ratio

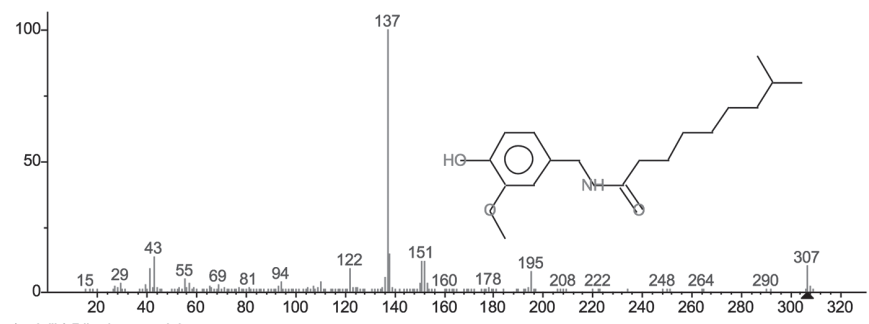

(mainlib) Dihydrocapsaicin

Figure 6. Mass spectra of dihydrocapsaicin, a plot of relative abundance against mass to charge ratio
Conflicts of interest: No conflict of interest was declared by the authors. The authors alone are responsible for the content and writing of this article.

\section{REFERENCES}

1. Birben E, Sahiner UM, Sackesen C, Erzurum S, Kalayci O. Oxidative stress and antioxidant defense. World Allergy Organ J. 2012;5:9-19.

2. Bogdan Al, Baumann L. Antioxidants used in skin care formulations. Skin Therapy Lett. 2018;13:5-9.

3. Tezel G. Oxidative stress in glaucomatous neurodegeneration: mechanisms and consequences. Prog Retin Eye Res. 2006;25:490-513.

4. Lobo V, Patil A, Phatak A, Chandra N. Free radicals, antioxidants and functional foods: Impact on human health. Pharmacogn Rev. 2010;4:118126.

5. Butterfield DA, Drake J, Pocernich C, Castegna A. Evidence of oxidative damage in Alzheimer's disease brain: central role for amyloid $\beta$-peptide. Trends Mol Med. 2001;7:548-554.

6. Agil A, Durán R, Barrero F, Morales B, Araúzo M, Alba F, Miranda MT, Prieto I, Ramírez M, Vives F. Plasma lipid peroxidation in sporadic Parkinson's. Role of the L-dopa. J Neurol Sci. 2006;240:31-36.

7. Kim JI, Cho SI, Kim NH, Jin JK, Choi EK, Carp RI, Kim YS. Oxidative stress and neurodegeneration in prion diseases. Ann N Y Acad Sci. 2001;928:182-186.

8. He L, He T, Farrar S, Linbao J, Liu T, Ma Xi. Antioxidants and Cellular Homeostasis by Elimination of Reactive Oxygen Species. Cell Physiol Biochem. 2017;44:532-553.

9. Pandey KB, Rizvi SI. Plant polyphenols as dietary antioxidants in human health and disease. Oxid Med Cell Longev. 2009;2:270-278.

10. Simo A, Kawal N, Paliyath G, Bakovic M. Botanical antioxidants for skin health in the world of cosmeceuticals. International Journal of Advanced Nutritional and Health Science. 2014;2:67-88.

11. López VGC, Cortés RC. Medicinal plants, antioxidants and health. J Tox Health. 2013;103:257-265.

12. Gülçin I, Berashvili D, Gepdiremen A. Antiradical and antioxidant activity of total anthocyanins from Perilla pankinensis decne. J Ethnopharmacol. 2005;101:287-293.

13. Irvine JR. Woody plants of Ghana. $2^{\text {nd }}$ ed. London: Oxford University press; 1961:51.

14. Abo KA, Ogunleye VO, Ashidi JS. Antimicrobial potential of Spondias mombin, Croton zambesicus and Zygotritonia crocea. Phytother Res. 1999;13:494-497.

15. Ajao AO, Shonukan O, Onadeko BF. Antibacterial effect of aqueous and alcohol extracts of Spondias mombin and Alchomea cordifolia - Two local antimicrobial remedies. Int J Crude Drug Res. 1985;23:67-72.

16. Akubue PI, Mittal GC, Aguwa CN. Preliminary pharmacological study of some Nigerian medicinal plants. J Ethnopharmacol. 1983;8:53-63.

17. Corthout J, Pieters LA, Claeys M, Vanden BDA, Viletinck AJ. Antiviral; Ellagitannins from Spodias mombin. Phytochemistry 1991;30:1129-1130.

18. Rodrigues KF, Hesse M, Werner C. Antimacrobial activities of secondary metabolites produced by endophytic fungi from Spondias mombin. J Basic Microbiol. 2000;40:261-267.

19. Villegas LF, Fernadz TD, Maldonado H, Torres R, Zavaleta A, Vaisberg AJ, Hammond GB. Evaluation of the wounds - healing activity of selected 
traditional medical plants from Peru. J Ethnopharmacol. 1997;55:193200.

20. Cabral B, Siqueira EMS, Bitencourt MAO, Lima MCJS, Lima AK, Ortmann CF, Chaves VC, Fernandes-Pedrosa MF, Rocha HAO, Scortecci KC, Reginatto FH, Giordani RB, Zucolotto SM. Phytochemical study and antiinflammatory and antioxidant potential of Spondias mombin leaves. Rev Bras Farmacogn. 2016;26:304-311.

21. Tiburski JH, Rosenthal A, Deliza R, De Oliveira Godoy RL, Pacheco S. Nutritional properties of yellow mombin (Spondias mombin L.) pulp. Food Res Int. 2011;44:2326-2331.

22. Kim DO, Jeong SW, Lee CY. Antioxidant capacity of phenolic phytochemicals from various cultivars of plums. Food Chem. 2003;81:321-326.

23. Park YS, Jung ST, Kang SG, Heo BG, Arancibia AP, Toledo F, Drzewiecki J, Namiesnik J, Gorinstein S. Antioxidants and proteins in ethylenetreated kiwifruits. Food Chem. 2008;107:640-648.

24. Silva EM, Souza JNS, Rogez H, Rees JF, Larondelle Y. Antioxidant activity and polyphenolic contents of fifteen selected plant species from the Amazonian region. Food Chem. 2006;101:1012-1018.

25. Ruch RJ, Cheng SJ, Klaunig JE. Prevention of cytotoxicity and inhibition of intracellular communication by antioxidant catechins isolated from Chinese green tea. Carcinogenesis. 1989;10:1003-1008.

26. Balakrishnan N, Panda AB, Raj NR, Shrivastava A, Prathani R. The evaluation of nitric oxide scavenging activity of Acalyphaindica Linn Root. Chem Asian J. 2009;2:148-150.

27. Mosmann T. Rapid colorimetric assay for cellular growth and survival: application to proliferation and cytotoxicity assays. J Immunol Methods.1983;65:55-63.

28. Wangchuk P, Navarro S, Shepherd C, Keller PA, Pyne SG, Loukas A. Diterpenoid alkaloids of Aconitum laciniatum and mitigation of inflammation by $14-0$-acetylneoline in a murine model of ulcerative colitis. Sci Rep. 2015;5:12845.

29. Sahreen S, Khan MR, Khan RA. Phenolic compounds and antioxidant activities of Rumex hastatus D. Don. Leaves. J Med Plant Res. 2011;5:2755-2765.

30. Akinmoladun AC, Khan MF, Sarkar J, Farombi EO, Maurya R. Distinct radical scavenging and antiproliferative properties of Spondias mombin and antioxidant activity-guided isolation of quercetin-3-0- $\beta$ Dglucopyranoside and undec-1-ene. Afr J Pharm Pharmacol. 2015;9:506513.
31. Kuskoski EM, Asuero AG, Morales MT, Fett R. Frutos tropicais silvestrese polpas de frutas congeladas: atividade antioxidante, polifenóise antocianinas. Ciênc Rural. 2006;36:1283-1287.

32. Nakatsuji T, Kao MC, Fang JY, Zouboulis CC, Zhang L, Gallo RL, Huang CM. Antimicrobial Property of Lauric acid against Propionibacterium acnes: Its Therapeutic Potential for Inflammatory Acne Vulgaris. J Invest Dermatol. 2009;129:2480-2488.

33. Anneken DJ, Both S, Christoph R, Fieg G, Steinberner U, Westfechtel, A. "Fatty Acids" in Ullmann's Encyclopedia of Industrial Chemistry. Weinheim: Wiley-VCH; 2006.

34. Meng Q, Yu M, Gu B, Li J, Liu Y, Zhan C, Xie C, Zhou J, Lu W. Myristic acid-conjugated polyethylenimine for brain-targeting delivery: In vivo and ex vivo imaging evaluation. J Drug Target. 2010;18:438-446.

35. Or-Rashid MM, Odongo NE, Subedi B, Karki P, McBride BW. Fatty acid composition of yak (Bos grunniens) cheese including conjugated linoleic acid and trans-18:1 fatty acids. J Agric Food Chem. 2008;56:1654-1660.

36. Aparna V, Dileep KV, Mandal PK, Karthe P, Sadasivan C, Haridas M. Antiinflammatory property of $n$-hexadecanoic acid: Structural evidence and kinetic assessment. Chem Biol Drug Des. 2012;80:434-439.

37. Graikou K, Kapeta S, Aligiannis N, Sotiroudis G, Chondrogianni N, Gonos E, Chinou L. Chemical analysis of Greek pollen-antioxidant, antimicrobial and proteasome activation properties. Chem Cent J. 2011;5:33.

38. Harada H, Yamashita U, Kurihara H, Fukushi E, Kawabata J, Kamei Y. Antitumor activity of palmitic acid found as a selective cytotoxic substance in a marine red alga. Anticancer Res. 2002;22:2587-2590.

39. Kumar P, Kumaravel S, Lalitha C. Screening of antioxidant activity, total phenolics and GC-MS study of Vitex negundo. Afr J Biochem Res. 2010;4:191-195.

40. Murakami K, Ito M, Htay HH, Tsubouchi R, Yoshino M. Antioxidant effect of capsaicinoids on the metal-catalyzed lipid perox idation. Biomed Res. 2001;22:15-17.

41. Fattori V, Hohmann MS, Rossaneis AC, Pinho-Ribeiro FA, Verri WA. Capsaicin: Current Understanding of Its Mechanisms and Therapy of Pain and Other Pre-Clinical and Clinical Uses. Molecules. 2016;21:844.

42. FDA. "FDA Approves New Drug Treatment for Long-Term Pain Relief after Shingles Attacks". U.S. Food and Drug Administration. 17 November 2009. Retrieved 5 January 2016.

43. Cechovska L, Cejpek K, Konecny M, Velısek J. On the role of 2,3-dihydro3,5-dihydroxy-6-methyl-(4H)-pyran-4-one in antioxidant capacity of prunes. Eur Food Res Technol. 2011;233: 367-376. 